\title{
Carcass traits and meat quality of Brangus $\times$ Zebu steers in grazing systems receiving
}

\section{supplementation}

Felipe Roberto Amaral Ferreira do Valle ${ }^{1 \oplus}$, Carlos Augusto de Alencar Fontes ${ }^{1 \oplus}$, Alberto Magno Fernandes ${ }^{1 \oplus}$, Tadeu Silva de Oliveira ${ }^{1 *} \odot$, Elizabeth Fonseca Processi2 ${ }^{\oplus}$

\author{
'Universidade Estadual do Norte Fluminense Darcy Ribeiro/ \\ CCTA - Lab. de Zootecnia, Av. Alberto Lamego, 2000 - \\ 28013-602 - Campos dos Goytacazes, RJ - Brasil. \\ 2Universidade Federal Rural do Rio de Janeiro, Av. Lourival \\ Martins Beda, s/n - 28022-560 - Campos dos Goytacazes, \\ RJ - Brasil. \\ *Corresponding author <tsoliveira@uenf.br>
}

Edited by: Antonio Faciola

Received August 23, 2019

Accepted November 08, 2019
ABSTRACT: The use of supplements eliminates deficiencies imposed by pasture, increases weight gain in animals and maximizes profits from the activity. The objective of this study was to evaluate the performance, carcass traits and meat quality of steers in grazing systems that received or did not receive a protein energy supplement at the level of $0.6 \%$ body weight. The experiment lasted 160 days and included 36 Brangus $\times$ Zebu animals. Eighteen animals received supplementation and another eighteen did not receive supplementation. Carcasses were evaluated for yield, loin eye area, fat thickness and length. The assessment of meat quality evaluated the shear force, myofibril fragmentation index, color, exudative losses and collagen. The carcass traits of the supplemented animals showed higher values $(p<0.0001)$. Supplementation improved the color of the meat $(p=0.0434)$ and increased the amount of soluble collagen $(p=0.0456)$. The use of a protein energy supplement for steers in a pasture system increased the efficiency of muscle deposition of these animals and improved meat quality when compared to animals that were not supplemented.

Keywords: crossing, muscle deposition, efficiency of use

\section{Introduction}

In Brazil, approximately $90 \%$ of bovine meat production is carried out on zebu (Bos indicus) cattle that have finished due pasturing, and are castrated and slaughtered between 30 and 42 months of age (ANUALPEC, 2018). The result is lower quality meat compared to meat from European animals (Bos taurus) that are slaughtered at a younger age (Prado et al., 2015). The use of crossbreeding of European and Zebu breeds due to heterosis and complementarity between these breeds improves productivity and produces meat with qualitative characteristics that are more widely accepted in both the national and international markets (Scollan et al., 2006).

Thus, the success of the beef cattle production system depends on the use of a set of technology and management practices and the examination of an animal's ability to produce meat with greater profitability. It is known that the consumer market is dynamic and constantly changing, and that demand for meat quality is increasing. As a result, Brazilian beef cattle farms have been specializing in improving management, reducing costs and increasing production efficiency (Sestari et al., 2012).

In meat production on pasture, the most limiting nutrient for weight gain is energy. This limitation is mainly due to insufficient intake and the low energy value of most forages (Horrocks and Vallentine, 1999). Although it is of vital importance, energy is considered to be a secondary nutrient, with a greater emphasis on the correction of protein deficiencies in tropical pastures. The use of supplements eliminates deficiencies imposed by pasturing, increasing the weight gain of the animals and maximizing the profits of the activity.
Thus, the goal of this study was to evaluate the influence of protein energy supplementation on performance, carcass traits and meat quality of steers in grazing systems.

\section{Materials and Methods}

This study was performed in strict accordance with the recommendations found in the Guide for the National Council for Animal Experiments Control and was approved by the Ethics Committee for Animal Experimentation (CEUA) of State University of Northern Rio de Janeiro, in the State of Rio de Janeiro, Brazil (Permit Number: 168-2012).

This experiment was carried out in Campos dos Goytacazes RJ, Brazil $\left(21^{\circ} 43^{\prime} \mathrm{S}, 41^{\circ} 20^{\prime} \mathrm{W}\right.$, altitude of $19 \mathrm{~m})$. This location has a tropical seasonal climate according to the Köppen classification (Köppen, 2011).

The experiment was conducted in an area of nine hectares of flat relief, cultivated with Mombaça grass (Magathyrsus maximus (Jacq.) equipped with a low-pressure sprinkler irrigation system and divided into 36 paddocks of 0.25 ha each.

The pasture was managed by intermittent stocking, and each experimental cycle consisted of periods of 4 days of occupation and 28 days of rest. During the experimental period, five grazing cycles were evaluated, totaling 160 days.

A total of 36 Brangus $\times$ Zebu animals were used, with an initial mean body mass of approximately 200 $\pm 5.2 \mathrm{~kg}$ and between 8 and 9 months of age. The animals were distributed at random in a paddock, and this set (animal/paddock) constitutes the repetition. Before the onset of the experiment, the animals were 
dewormed as a protective measure against endo- and ectoparasites.

The treatments consisted of protein energy supplementation (PES) and non-supplementation (NPES). Animals were individually given $6 \mathrm{~g} \mathrm{~kg}^{-1} \mathrm{PES}$ body weight. The adaptation period lasted 32 days, during which the animals completed a grazing cycle in the experimental area and were subjected to the same grazing and management conditions established for the experimental period. At the beginning of each grazing cycle, the animals were weighed to determine the amount of supplement which consisted of ground corn, wheat meal and soybean meal (Table 1). For each grazing cycle, the individual amount of the supplement provided was adjusted to $0.6 \%$ body weight (BW) of the animals. The mineral mixture was supplied individually in the amount of $100 \mathrm{~g} \mathrm{~d}^{-1}$ for all animals.

Individual pasture intake by animals was estimated using the double indicator technique - chromic oxide (external indicator) and lignin in potassium permanganate (internal indicator) as described by Van Soest (1994). In each cycle, $6 \mathrm{~g}$ of chromic oxide was supplied twice a day, at $09 \mathrm{~h} 00$ and $17 \mathrm{~h} 00$, via an esophageal tube for 13 consecutive days. After seven days, fecal sampling was initiated, lasting six days, in which the samples were obtained by rectal collection, twice a day, at the moment of supplying the indicator. Subsequently, after drying and grinding the fecal samples, a composite sample was made for each animal, corresponding to each period of fecal collection.

To obtain representative samples, forage was collected in the paddocks using the simulated grazing technique, during the same period of fecal collection. Composite samples of forage were made (repetition of area/collection period). Composite samples of supplement (offered and leftovers), feces and forage were dried at $\pm 55^{\circ} \mathrm{C}$ and ground to $1 \mathrm{~mm}$ to determine dry matter (method 967.03; AOAC, 1990), crude protein (method 981.10; AOAC, 1990), ether extract (method 920.29; AOAC, 1990), ash (method 942.05; AOAC, 1990) and lignin (method 973.18; AOAC, 2002) adopted as an internal indicator.

For chromium dosages, a nitro-perchloric digestion procedure was performed and then read on a UV visible

Table 1 - Ingredients and chemical composition in the experimental supplement.

\begin{tabular}{lc}
\hline Ingredients & Protein energy supplementation \\
\hline & $\mathrm{g} \mathrm{kg}^{-1}$ \\
Ground corn & 600.0 \\
Soybean meal & 10.0 \\
Wheat meal & 30.0 \\
\hline & Chemical composition \\
\hline Dry matter & 833.5 \\
Crude protein & 160.4 \\
Ether extract & 11.5 \\
Mineral matter & 33.0 \\
\hline
\end{tabular}

spectrophotometer at $440 \mathrm{~nm}$ (SPEKOL UV visible apparatus) as described by Williams et al. (1962). Fecal excretion was estimated using the following equation:

Fecal output $\mathrm{g} \mathrm{d}^{-1}=$ chromium supplied (g) / [chromium in feces $\left.\mathrm{g} \mathrm{kg}^{-1} D M\right]$

Thus, intake was estimated disregarding the lignin content of the supplement as it is negligible (Detmann et al., 2001), according to the following equations:

Forage intake $\left(\mathrm{kg} \mathrm{d}^{-1}\right)=(E F \times F a e L C) / F o L C$

Total dry matter intake $\left(\mathrm{kg} \mathrm{d}^{-1}\right)=$ forage intake + supplement intake

where: $E F=$ fecal excretion $\left(\mathrm{g} \mathrm{d}^{-1}\right) ; F a L C=$ fecal lignin concentration $(\mathrm{g})$ and $F O L C=$ forage lignin concentration (g).

The supplement was provided daily in individual stalls. Animals remained in the stalls from $09 \mathrm{~h} 00$ to $13 \mathrm{~h} 00$; the rest of the time they were on pasture. The animals assigned to the treatment without supplementation were subjected to the same management, except for the supplement offer. All animals, including nonsupplemented animals, received mineral salt in individual stalls. The individual supplement leftovers were collected daily from the trough, weighed, and a sample was taken to form the composite samples of leftovers per grazing cycle. The samples were pre- dried in an oven at $\pm 55^{\circ} \mathrm{C}$ for $72 \mathrm{~h}$ to further determine the chemical composition.

The animals were weighed four times after $16 \mathrm{~h}$ fasting during the experimental period, one weighing at the beginning, two intermediate and one at the end.

At the beginning of the experimental period and the end of each grazing cycle, immediately after weighing each animal, the animals were individually restrained and measured by ultrasonography to obtain the loin-eye area (LEA) $\left(\mathrm{cm}^{2}\right)$. For this measurement, the region between the $12^{\text {th }}$ and $13^{\text {th }}$ ribs on the left side of the animal was cleaned and lubricated with vegetable oil. The transducer was placed perpendicular to the length of the Longissimus dorsi muscle and slowly moved until it obtained an ultrasound image with welldefined muscle contours. The image was frozen and, and adequate visualization of the muscle was confirmed, identified by animal and stored on hard disk for later determination of LEA, according to the methodology described by Suguisawa et al. (2006). For the procedure, ultrasound equipment was used, with a $3.5 \mathrm{MHz}, 18 \mathrm{~cm}$ wide linear transducer.

Before slaughter, the animals were weighed after a 16-h fast, stunned with a screw gun, hung upside down and bled through a cut in the jugular vein. The slaughter was carried out in an official slaughterhouse in accordance with federal norms prescribed for the humanitarian slaughter of cattle. 
The two half-carcasses were weighed hot and taken to the cold chamber where they remained at $4{ }^{\circ} \mathrm{C}$ for 24 h. After cooling, the carcasses were reweighed, and the hot and cold carcass yields, as well as the carcass length, were determined. The subcutaneous fat thickness (SFT) and the loin-eye area were determined in the left half of the carcass, next to the $12^{\text {th }}$-rib.

For the analyses of losses, frozen Longissimus dorsi samples (steaks) were used. The steaks were thawed for $16 \mathrm{~h}$ at $4{ }^{\circ} \mathrm{C}$ and weighed before and after thawing to determine thawing losses expressed as a percentage of the weight before cooking. Next, the steaks were cooked in a preheated electric oven, with their internal temperatures monitored with a type-K probe thermometer positioned at the geometric center of each steak. Steaks were removed from the electric oven when the internal temperature reached $71^{\circ} \mathrm{C}$. The cooking loss was calculated as the difference in sample weight before $\left(\mathrm{W}_{\mathrm{b}}\right)$ and after cooking $\left(\mathrm{W}_{\mathrm{a}}\right)$, and was expressed as a percentage of the initial sample weighing: Cooking loss $(\%)=\left[\left(W_{b}-W_{a}\right) / W_{b}\right] \times 100$. Total losses were obtained from the difference in weight between the frozen and cooked samples.

The samples used for the cooking loss analysis were also used for shear force measurements. For the shear force test, six cylindrical samples, approximately $13 \mathrm{~mm}$ in diameter, were removed from each steak. The longitudinal axis of the sample was parallel to the direction of the muscle fibres to ensure that the sample was sheared at right angles to the fibre axis. Shear force was determined with a Warner-Bratzler Shear Force unit with a capacity of $25 \mathrm{~kg}$, as described by AMSA (2015). The results are expressed in Newtons (N).

The myofibrillar fragmentation index was determined according to Culler et al., 1978. Four grams of minced muscle were homogenized for $30 \mathrm{~s}$ in $10 \mathrm{vol}\left(\mathrm{v} \mathrm{w}^{-1}\right)$ of a $2{ }^{\circ} \mathrm{C}$ isolating medium consisting of $100 \mathrm{mM} \mathrm{KCl}, 20 \mathrm{mM} \mathrm{K}$ phosphate, 1 $\mathrm{mM}$ EDTA, $1 \mathrm{mM} \mathrm{MgCl}$, and $1 \mathrm{mM}$ sodium azide. The homogenate was centrifuged at $1000 \times \mathrm{g}$ for $15 \mathrm{~min}$ and then the supernatant was decanted. The sediment was then resuspended in $10 \mathrm{vol}\left(\mathrm{v} \mathrm{w}^{-1}\right)$ of isolating medium using a stir rod, centrifuged again at 1000 $\times \mathrm{g}$ for $15 \mathrm{~min}$ and the supernatant was decanted. The sediment was resuspended in $2.5 \mathrm{vol}\left(\mathrm{v} \mathrm{w}^{-1}\right)$ of isolating medium and passed through a polyethylene strainer (18 mesh) to remove connective tissue and debris. An additional $2.5 \mathrm{vol}\left(\mathrm{v} \mathrm{w}^{-1}\right)$ was used to facilitate passage of myofibrils through the strainer. The protein concentration of the myofibril suspension was determined by the biuret method as described by Gornall et al. (1949). Sarcomere length was measured using approximately $1 \mathrm{~g}$ of the central portion of the sample from the longissimus muscle (between the $12^{\text {th }}$ and $13^{\text {th }}$ ribs), which was removed with forceps and a scalpel and immersed in $0.2 \mathrm{M}$ buffered sucrose according to Crosset al., 1981. The sample was then mounted in a tissue chamber, and the sarcomere length was measured with a helium-neon laser (1 mW) on a wavelength of $632.8 \mathrm{~nm}$.

The color index of the meat was measured on a fresh cut using a colorimeter. The CIE L* (lightness), $a^{*}$ (redness) and $b^{*}$ (yellowness) values were measured (Illuminant D65, $8 \mathrm{~mm}$ aperture, $0^{\circ}$ standard observer). Thirty minutes before the evaluations at different points of the meat sample, a cross section of the muscle was cut to expose the myoglobin to oxygen. After, $L^{*}, a^{*}, b^{*}$ values were determined according to the Cielab system. Collagen and its fractions were quantified using hydroxyproline, as described by Woessner Jr. (1961). Samples were hydrolyzed in an autoclave at $120^{\circ} \mathrm{C}$ and 1 atm for $4 \mathrm{~h}$ (Cross et al., 1973).

The mean values of the PES and NPES treatment animals were compared with analyses of variance and contrasts were performed using the CONTRAST of PROC GLM procedure of SAS (Statistical analysis System, version 9.2) and area effect was analyzed BY SAS' REPEATED statement adopting a $5 \%$ probability.

The following statistical model was used: $Y_{i j k}=$ $\mu+\alpha_{i}+R_{j}+\alpha R_{i j}+e_{i j k^{\prime}}$ where: $Y_{i j k}$ is the observation concerning animal $k$, receiving supplement $i$ in area; $j$ repetition; $\mu$ the overall mean; $\alpha_{i}$ the supplement; where $i=1$ the protein energy supplement and where $i=2$ is not supplemented; $R_{j}$ is the area of repeat effect; $\alpha R_{i j}$ the interaction between supplement and area of repetition; and $e_{i j}$ the random error.

\section{Results}

No interaction $(p>0.05)$ between supplement and area of repetition were observed for the variables analyzed.

Supplementation did not affect $(p=0.3742)$ the voluntary forage intake by animals (Table 2). The forage consumed by the animals presented an average content of $226.5 \mathrm{~g} \mathrm{~kg}^{-1}$ dry matter and $84.9 \mathrm{~g} \mathrm{~kg}^{-1}$ crude protein. Animals receiving protein energy supplementation increased total dry matter intake $(p<0.0001)$, total neutral detergent fiber intake $(p=0.0056)$ and total protein intake $(p<0.0001)$ (Table 2$)$.

The impact of this increase on total nutrient intake was observed in the average daily gain of animals that received supplementation, who gained three times more weight than animals that were not supplemented (Table $2)$. The feed efficiency of the supplemented animals was $13.57 \%(0.536 / 3.95)$, as against $4.75 \%(0.178 / 3.75)$ in animals that were not supplemented, which is $65.46 \%$ lower than the supplemented animals.

Improvement in the carcass traits of the supplemented animals is presented in Table 3. The cold carcass weight was $27 \%$ higher $(p<0.001)$ for the supplemented animals than for the non-supplemented animals (157.84 × $115.56 \mathrm{~kg})$. 
Table 2 - Nutrient intake and average daily gain of steers Brangus $\times$ Zebu submitted to the protein energy supplementation (PES) and non-supplementation (NPES).

\begin{tabular}{llllc}
\hline \multirow{2}{*}{ Item } & \multicolumn{2}{c}{ Treatments } & \multirow{2}{*}{ SEM } & \multirow{2}{*}{$p$-value } \\
\cline { 2 - 3 } & PES & NPES & & \\
\hline IF $\left(\mathrm{kg} \mathrm{d}^{-1}\right)$ & 3.95 & 3.75 & 0.071 & 0.3742 \\
SI $\left(\mathrm{kg} \mathrm{d}^{-1}\right)$ & 1.59 & 0.065 & 0.539 & $<0.001$ \\
TDMI $\left(\mathrm{kg} \mathrm{d}^{-1}\right)$ & 5.54 & 3.82 & 0.608 & $<0.001$ \\
FCPI $\left(\mathrm{kg} \mathrm{d}^{-1}\right)$ & 0.32 & 0.32 & 0.000 & 0.9785 \\
TCPI $\left(\mathrm{kg} \mathrm{d}^{-1}\right)$ & 0.53 & 0.32 & 0.074 & $<0.001$ \\
FFI $\left(\mathrm{kg} \mathrm{d}^{-1}\right)$ & 2.66 & 2.6 & 0.021 & 0.6617 \\
TFI $\left(\mathrm{kg} \mathrm{d}^{-1}\right)$ & 3.02 & 2.6 & 0.148 & 0.0056 \\
ADG $\left(\mathrm{kg} \mathrm{d}^{-1}\right)$ & 0.536 & 0.178 & 0.127 & $<0.001$ \\
\hline
\end{tabular}

$\mathrm{IF}=$ Forage intake; $\mathrm{SI}=$ Supplement intake; TDMI = Total dry matter intake; $\mathrm{FCPI}=$ Forage crude protein intake; $\mathrm{TCPI}=$ Total crude protein intake; $\mathrm{FFI}=$ Forage neutral detergent fiber intake; TFI = Total forage neutral detergent fiber intake; $A D G$ = Average daily gain; SEM = Standard error of the means.

Table 3 - Empty Body weight, body weight fasting, and carcass characteristics of steers Brangus $\times$ Zebu submitted to protein energy supplementation (PES) and non-supplementation (NPES).

\begin{tabular}{|c|c|c|c|c|}
\hline \multirow{2}{*}{ Item } & \multicolumn{2}{|c|}{ Treatments } & \multirow{2}{*}{ SEM } & \multirow{2}{*}{$p$-value } \\
\hline & PES & NPES & & \\
\hline $\mathrm{n}$ & 18 & 18 & & \\
\hline BWF (kg) & 292.61 & 225.79 & 23.62 & $<0.0001$ \\
\hline EBW (kg) & 252.69 & 191.67 & 21.57 & $<0.0001$ \\
\hline HCW (kg) & 160.56 & 119.38 & 14.56 & $<0.0001$ \\
\hline CCW (kg) & 157.84 & 115.56 & 14.95 & $<0.0001$ \\
\hline SFT (mm) & 2.14 & 0.27 & 0.66 & $<0.0001$ \\
\hline $\mathrm{CL}(\mathrm{m})$ & 1.2 & 1.15 & 0.02 & 0.0015 \\
\hline $\mathrm{CL}\left(\mathrm{m} 100 \mathrm{~kg}^{-1}\right)$ & 0.48 & 0.6 & 0.04 & $<0.0001$ \\
\hline LEA $\left(\mathrm{cm}^{2}\right)$ & 43.79 & 34.88 & 3.15 & 0.0003 \\
\hline \multicolumn{5}{|c|}{ Yield body weight fasting (\%) } \\
\hline$\overline{\mathrm{HCW}}$ & 54.89 & 52.88 & 0.71 & $<0.0001$ \\
\hline CCW & 53.92 & 51.17 & 0.97 & $<0.0001$ \\
\hline
\end{tabular}

The use of the supplement gave the supplemented animals a fat thickness $87 \%$ greater $(p<0.001)$, and $20.27 \%(p=0003)$, of the loin-eye area than the nonsupplemented animals (Table 3).

Supplementation increased $(p<0.001)$ the cold carcass yield of supplemented animals by approximately $5 \%(53.92 \times 51.17 \%)$ compared with the nonsupplemented animals.

No effect of the treatments on shear force $(p=$ $0.9903)$ and myofibrillar fragmentation index $(p=$ 0.0592) was detected (Table 4).

As regards color, only the $\mathrm{a}^{*}$ value (red intensity) differed between treatments $(p=0.0434)$. For losses, the supplemented animals had higher cooking losses $(p=$ $0.0397)$ than the non-supplemented animals. There was a difference $(p=0.0456)$ in soluble collagen; animals receiving supplementation had $2 \%$ more soluble collagen than those that had no supplementation (Table 4).
Table 4 - Meat quality of steers Brangus $\times$ Zebu submitted the protein energy supplementation (PES) and non-supplementation (NPES).

\begin{tabular}{|c|c|c|c|c|}
\hline \multirow{2}{*}{ Item } & \multicolumn{2}{|c|}{ Treatments } & \multirow{2}{*}{ SEM } & \multirow{2}{*}{$p$-value } \\
\hline & PES & NPES & & \\
\hline$n$ & 18 & 18 & & \\
\hline SF (N) & 25.59 & 25.59 & 0 & 0.9903 \\
\hline MFI (\%) & 63.3 & 56.37 & 2.45 & 0.0592 \\
\hline \multicolumn{5}{|c|}{ Color } \\
\hline L (lightness)* & 27.95 & 29.74 & 0.63 & 0.0867 \\
\hline$a$ (redness) $^{*}$ & 10.05 & 9 & 0.37 & 0.0434 \\
\hline b (yellowness)* & 9.44 & 8.88 & 0.19 & 0.2762 \\
\hline \multicolumn{5}{|c|}{ Losses (\%) } \\
\hline Thawing & 5.49 & 3.86 & 0.57 & 0.0833 \\
\hline Cooking & 14.07 & 12.2 & 0.66 & 0.1037 \\
\hline Total & 19.56 & 16.06 & 1.23 & 0.0397 \\
\hline \multicolumn{5}{|c|}{ Collagen } \\
\hline Total $\left(\mathrm{mg} \mathrm{g}^{-1}\right)$ & 12.86 & 11.28 & 0.56 & 0.4145 \\
\hline Total (\%) & 1.29 & 1.13 & 0.05 & 0.4175 \\
\hline Soluble (\%) & 90.42 & 88.6 & 0.64 & 0.0456 \\
\hline
\end{tabular}
animals; SEM = Standard error of the means.

\section{Discussion}

Supplementation did not cause any decline in voluntary forage intake (Table 2); possibly there was no substitution effect of forage by supplementation. The degree and magnitude of occurrence of the substitution effect depends on the availability (quantity and quality) of pasture offered (Vaz et al., 2013; McLennan et al., 2017). In the present study, the forage supply was kept regular and constant at $6 \% \mathrm{BW}$ in dry green mass $\mathrm{d}^{-1}$, there was probably little variation in pasture quality over the experimental period (forage consumed by animals averaging $84.9 \mathrm{~g} \mathrm{~kg}^{-1} \mathrm{CP}$ ).

The efficiency of utilization of metabolizable energy (ME) of the forage can be optimized by the use of supplementation which reduces deficiencies in the nutrients by maximizing microbial growth, resulting in the enhancement of forage carbohydrate extraction during fermentation, and increases in the production of short chain fatty acids. Moreover, increased total protein intake (Table 2) may provide greater rumen microbial protein synthesis (Tedeschi et al., 2015).

When analyzing the additional daily average gain, which represents an increase in weight gain provided by supplement use, we observed a $358 \mathrm{~g} \mathrm{~d}^{-1}$ increase in animal performance compared to non-supplemented animals (Table 2). These additional gains obtained at this stage may result in the slaughter of animals under the age of 20 months, resulting in higher capital turnover and cost savings. The use of protein energy supplements at this stage is important due to the higher feed efficiency of the animals, bringing greater economic and productive return to the producer (Sales et al., 2011). 
The age at which the animal is slaughtered may influence the composition of the carcass (bone/ meat/fat ratio). The growth of the animals presents allometric characteristics, where each tissue has, at a given moment, a different rate of growth. The rate of muscle growth depends on the protein turnover, that is, on the relationship between protein metabolism and catabolism. Growth will occur when the anabolic increase overcomes catabolic losses (Buttery, 1981; Goll et al., 2008).

Thus, protein energy supplementation provides animals with a greater supply of nutrients, leading to observations of better muscle yield in the animals (Table 3). The loin-eye area measurements suggest that supplementation was efficient in increasing the muscular yield of animals, since this is a measurement that allows for estimating the yield of carcass muscle yield (Suguisawa et al., 2006). In the present study, the LEA values of supplemented animals were higher $(p$ $=0.003$ ) than those of the non-supplemented animals (43.79 vs 34.88 , respectively).

On the other hand, even the animals that were supplemented had carcasses with low SFT $(2.14 \mathrm{~mm})$, probably due to the early slaughter age. This low SFT is found in the pasture-based steer farming system; at this stage, there is a high deposition rate of muscle tissue since young animals are more efficient in the conversion of nutrients, mainly protein (Berg and Butterfield, 1976). In the order of tissue deposition, the fat is the last, so early animals will not have well-finished carcasses. The subcutaneous fat thickness should be between 3 and 6 $\mathrm{mm}$ for better preservation and avoidance of damage to the carcass during cooling (shortening by cold, which causes reduced tenderness). Moreover, lower fat levels impact quality such as taste and succulence (Avilés et al., 2015).

Carcass length is directly related to the development of the bone tissue of the animal at the time of the evaluations and, therefore, to the growth phase of the animal. The impact of each treatment is in relation to bone growth and the duration of the treatments (Pazdiora et al., 2013). When the carcass length is expressed, per 100 kg empty body mass indicates the animal compactness. Therefore, the animals that were supplemented had greater soft tissue development, presenting a lower value of carcass length per $100 \mathrm{~kg}^{-1}$ empty body weight, that is, higher body mass per unit length (Table 3).

Muscle hypertrophy, favored by animal supplementation and stimulated by sex hormones (Kuradomi et al., 2011), causes an increase in enzyme activity, especially calpastatin (Goll et al., 1998). On the other hand, the non-supplementation of animals can reduce this activity (Du et al., 2004) and, thus, muscle atrophy, especially of less energy-efficient muscle fibers (Lehnert et al., 2006). This phenomenon is presented in Table 4 , in which there was evidence ( $p=0.0592)$ that the supplemented animals had a higher myofibril fragmentation index $(63.30 \%)$ than non-supplemented animals (56.37 \%). Myofibrillar proteins are directly related to the protein turnover given by the balance between the protein synthesis and degradation (Goll et al., 1998). Thus, the fragmentation index allows us to infer that myofibrillar proteolysis was greater than synthesis.

The shear force is another variable that has a direct effect on the tenderness of the meat. In this study, there was no difference between the supplemented and non-supplemented animals in relation to shear force, with values $25.59 \mathrm{~N}$ below those recommended by Shackelford et al. (1991), who considers meat up to $44.12 \mathrm{~N}$ as tender; thus our results demonstrated meat with good softness. Despite the scarcity of subcutaneous fat there was probably no shortening of muscle fibers attributable to the cold.

Color causes the first impact on the consumer, arousing the desire to consume or reject the product, and is an indication, although not always correct, about the degree of food preservation. The main pigment in meat associated with color is myoglobin. Hemoglobin, the blood pigment, is second in importance. For Purchas (2012), the range considered ideal for the lightness index $\left(\mathrm{L}^{*}\right)$ is between 34 and 39 ; the results obtained in the present study, as well as the $a^{*}$ values, are below this range. Although the animals that were supplemented had higher values $(p=0.04434)$, these values were still below the range proposed by Purchas (2012) between 18 and 22 to characterize the meats as red. These values are expected since the slaughtered animals are very young and less physically active, and because the content of myoglobin in cattle increases rapidly until 24-36 months of age, at which point the animals are more physically active, causing a greater demand for energy prioritizing the red fibers of oxidative metabolism (SäNger and Stoiber, 2001).

Another visual aspect of meat quality is the exudative losses related to the shortening of muscle fibers due to the cold, arising from the scarcity of subcutaneous fat of the animals $(<1 \mathrm{~mm})$ and the low temperature of cooling imposed on the carcasses. According to Polizel Neto et al. (2009), cooking losses range between 20.3 and $33.1 \%$; the results obtained in the present study were 16.06 and $19.56 \%$ (NPES and PES, respectively), as presented in Table 4.

Collagen is an important component of connective tissue. With the maturity of the animal, the rigidity of collagen increases due to the enhancement in the stability of the cross-linking between the collagen molecules, providing structural support to the skeletal muscles. Collagen is the main component responsible for the structural stiffening in postmortem meat and is an important determinant of the variability in meat texture between muscles (Archiles-Contreras et al., 2010). There is a decrease in total collagen and/or increase in collagen solubility of animals fed energy-rich diets (Silva et al., 2010), and this fact corroborates the results of this study: $90.42 \times 88.60 \%$ (Table 4). 


\section{Conclusion}

The use of protein energy supplements for steers on pasture increased the efficiency of muscle deposition of these animals and provided improved meat quality when compared to animals that had not been supplemented.

\section{Authors' Contributions}

Conceptualization: Valle, F.A.F; Fontes, C.A.A.; Fernandes, A.M.; Oliveira, T.S.; Processi, E.F. Data acquisition: Valle, F.A.F.; Fontes, C.A.A.; Fernandes, A.M.; Oliveira, T.S. Data analysis: Valle, F.A.F.; Fontes, C.A.A.; Fernandes, A.M.; Oliveira, T.S.; Processi, E.F. Design of methodology: Valle, F.A.F.; Fontes, C.A.A.; Processi, E.F. Writing and editing: Valle, F.A.F.; Fontes, C.A.A.; Fernandes, A.M.; Oliveira, T.S.; Processi, E.F.

\section{References}

American Meat Science Association [AMSA]. 2015. Research Guidelines for Cookery, Sensory Evaluation and Instrumental Tenderness Measurements of Fresh Meat. AMSA, Champaign, IL, USA.

Anuário da Pecuária Brasileira [ANUALPEC]. 2018. Brazilian cattle ranching yearbook. Available at: http://www.editoragazeta. com.br/produto/anuario-brasileiro-da-pecuaria-2018/ [Accessed May 10, 2019]

Archile-Contreras, A.C.; Mandell, I.B.; Purslow, P.P. 2010. Disparity of dietary effects on collagen characteristics and toughness between two beef muscles. Meat Science 86: 491497.

Avilés, C.; Martínez, A.L.; Domenech, V.; Penã, F. 2015. Effect of feeding system and breed on growth performance, and carcass and meat quality traits in two continental beef breeds. Meat Science 107: 94-103.

Berg, R.T.; Butterfield, R.M. 1976. New Concepts of Cattle Growth. Halsted Press, New York, NY, USA.

Buttery, P.J. 1981. Protein turnover in animals. Tropical Animal Health and Production 6: 204-213.

Cross, H.R.; Carpenter, Z.L.; Smith, G.C. 1973. Effects of intramuscular collagen and elastin on bovine muscle tenderness. Journal of Food Science 38: 998-1003.

Cross, H.R.; West, R.L.; Dutson, T.R. 1981. Comparison of methods for measuring sarcomere length in beef semitendinosus muscle. Meat Science 5: 261-266.

Culler, R.D.; Smith, G.C.; Cross, H.R. 1978. Relationship of myofibril fragmentation index to certain chemical physical and sensory characteristics of bovine longissimus muscle. Journal of Food Science 43: 1177-1180.

Du, M.; Zhu, M.J.; Means, W.J.; Hess, B.W.; Ford, S.P. 2004. Effect of nutrient restriction on calpain and calpastatin content of skeletal muscle from cows and fetuses. Journal of Animal Science 82: 2541-2547.

Goll D.E.; Thompson, V.F.; Taylor, G.R.; Ouali, A. 1998. The calpain system and skeletal muscle growth. Canadian Journal of Animal Science 78: 503-512.
Goll, D.E.; Neti, G.; Mares, S.W.; Thompson, V.F. 2008. Myofibrillar protein turnover: the proteasome and the calpains. Journal of Animal Science 86: 19-35.

Gornall, A.G.; Bardawill, C.J.; David, M.M. 1949. Determination of serum proteins by means of the biuret reaction. Journal of Biological Chemistry 177: 751-766.

Horrocks, R.D.; Vallentine, J.F. 1999. Harvested Forages. Academic Press, San Diego, CA, USA.

Lehnert, S.A.; Byrne, K.A.; Reverter, A.; Nattrass, G.S.; Greenwood, P.L.; Wang, Y.H.; Hudson, N.J.; Harper, G.S. 2006. Gene expression profiling of bovine skeletal muscle in response to and during recovery from chronic and severe undernutrition. Journal of Animal Science 84: 3239-3250.

Köppen, W. 2011. The thermal zones of the Earth according to the duration of hot, moderate and cold periods and to the impact of heat on the organic world. Meteorologische Zeitschrift 20: 351-360.

Kuradomi, R.Y.; Figueiredo, M.A.; Lanes, C.F.C.; Rosa, C.E.; Almeida, D.V.; Maggioni, R.; Silva, M.D.P.; Marins, L.F. 2011. $\mathrm{GH}$ overexpression causes muscle hypertrophy independent from local IGF-I in a zebrafish transgenic model. Transgenic Research 20: 513-52.

McLennan, S.R.; Bolam, M.J.; Kidd, J.F.; Chandra, K.A.; Poppi, D.P. 2017. Responses to various protein and energy supplements by cattle fed low-quality tropical hay. 1 . Comparison of response surfaces for young steers. Animal Production Science 57: 473-488.

Prado, I.N.; Eiras, C.E.; Fugita, C.A.; Oassetti, R.A.C.; Ornaghi, M.G.; Rivaroli, D.C.; Pinto, A.A.; Moletta, J.L. 2015. Animal performance and carcass characteristics of bulls $(1 / 2$ Purunâ vs $1 / 2$ Canchim) slaughtered at 16 and 22 months old, and three different weights. Asian-Australisian Journal of Animal Sciences 28:612-619.

Pazdiora, R.D.; Resende, F.D.; Faria, M.H.; Siqueira, G.R.; Almeida, G.B.S.; Sampaio, R.L.; Pacheco, P.S.; Prietto, M.S.R. 2013. Animal performance and carcass characteristics of Nellore young bulls fed coated or uncoated urea slaughtered at different weights. Revista Brasileira de Zootecnia 42: 273283.

Polizel Neto, A.; Jorge, A.M.; Moreira, P.S.A. 2009. Performance and quality of beef from Nellore and F1 Brangus x Nellore steers supplied with chromium attached to the organic molecule finished under grass conditions. Revista Brasileira de Zootecnia 38: 737-745 (in Portuguese, with abstract in English).

Purchas, R.W. 2012. Carcass evaluation. p. 333-356. In: Hui, Y. H., ed. Handbook of meat and meat processing, CRC Press, Boca Raton, FL, USA.

Sales, M.F.L.; Paulino, M.F.; Valadares Filho, S.C.; Figueiredo, D.M.; Porto, M.O.; Detmann, E. 2011. Supplementation levels for growing beef cattle grazing in the dry-rainy transition season. Revista Brasileira de Zootecnia 40: 904911.

Scollan, N.; Hocquette, J. F.; Nuernberg, K.; Dannenberger, D.; Richardson, I.; Moloney, A. 2006. Innovations in beef production systems that enhance the nutritional and health value of beef lipids and their relationship with meat quality. Meat Science 74: 17-33. 
Sestari, B.B.; Mizubuti, I.Y.; Ribeiro, E.L.A.; Barbosa, M.A.A.F.; Pereira, E.S.; Pinto, A.P.; Cunha, G.E.; Gomes, R.C.; Massaro Junior, F.L.; Rosolem, C.P. 2012. Carcass characteristics, noncarcass components and meat quality of Nellore cattle in a feedlot and fed with different corn hybrids. Semina: Ciências Agrárias 33: 3389-3400.

Shackelford, S.D.; Koohmaraie, M.; Miller, M.F.; Crouse, J.D.; Reagan, J.O. 1991. An evaluation of tenderness of the Longissimus muscle of Angus by Hereford versus Brahman crossbred heifers. Journal of Animal Science 69: 171-177.

Silva, C.C.G.; Rego, O.A.; Simões, E.R.E.; Rosa, H.J.D. 2010. Consumption of high energy maize diets is associated with increased soluble collagen in muscle of Holstein bulls. Meat Science 86: 753-757.

Suguisawa, L.; Mattos, W.R.S.; Oliveira, H.N.; Silveira, A.S.; Arrigoni, M.B.; Souza, A.A. 2006. Correlations between ultrasound measurements and carcass composition of young bulls. Revista Brasileira de Zootecnia 35: 169-176 (in Portuguese, with abstract in English).
Tedeschi, L.O.; Fox, D.G.; Fonseca, M.A.; Cavalcanti, L.F.L. 2015. Models of protein and amino acid requirements for cattle. Revista Brasileira de Zootecnia 44: 109-132.

Vaz, R.Z.; Lobato, J.F.P.; Pacheco, P.S. 2013. Performance of Braford steers grazing on cultivated pastures and fed or not fed an energy supplement. Revista Brasileira de Zootecnia 42: 130-136.

Williams, C.H.; David, D.J.; Iismaa, O. 1962. The determination of chromic oxide in feces samples by atomic absorption spectrophotometry. Journal of Agricultural Science 59: 381385.

Woessner Junior, J.F. 1961. The determination of hydroxyproline in tissue and protein samples containing small proportions of this amino acid. Archives of Biochemistry and Biophysics 93: 440-447. 